Nemanja Stanišić ${ }^{1}$

Vule Mizdraković ${ }^{2}$

Goranka Knežević ${ }^{3}$
JEL: M21, G33

DOI: 10.5937/industrija41-4024

UDK:347.736(497.11);005.521:334.7

Original Scientific Paper

\title{
Corporate Bankruptcy Prediction in the Republic of Serbia ${ }^{4}$
}

Article history:

Received: 13 Jun 2013

Sent for revision: 4 September 2013

Received in revised form: 5 November 2013

Accepted: 11 November 2013

Available online: 26 November 2013

Abstract: The aim of this paper is to present corporate default prediction models constructed in the specific market conditions that prevail in the Republic of Serbia, and to compare their prediction accuracy with the most frequently used model - Altman's Z-score. Many authors have constructed models for the purpose of bankruptcy prediction, but predominantly in stable market conditions or in times of economic growth. We have presented three models that use standard ratios and some specific variables in order to predict corporate bankruptcy in emerging and distressed markets. For that purpose, we have used the following statistical and machine learning methods on a training sample (130 companies): Logistic Regression, Decision Trees and Artificial Neural Networks. Finally, we have compared accuracies of predictions of our models to those of the Altman's Z-score models using an independent hold-out sample (102 companies). Results show that, out of the aforementioned three models, only the one relying on the artificial neural network algorithm performs better when applied on the hold-out sample, compared to Altman's Z-score models.

Keywords: Emerging markets, Altman's Z-score, default prediction models, financial ratios, Artificial Neural Network.

\footnotetext{
${ }^{1}$ Singidunum University , Faculty of Business, Belgrade, nstanisic@singidunum.ac.rs

${ }^{2}$ Singidunum University , Faculty of Business, Belgrade, vmizdrakovic@singidunum.ac.rs

${ }^{3}$ Singidunum University , Faculty of Business, Belgrade, gknezevic@singidunum.ac.rs

${ }^{4}$ This article in part represents fraction of original doctoral dissertation written and defended by Vule Mizdrakovic (dissertation available at: http://www.singipedia.com/content/3276-Komparativna-analiza-ekonomskih-aspekataste\%C4\%8Daja )
} 


\section{Predviđanje otvaranja stečajnog postupka u Republici Srbiji}

Apstrakt: Cilj ovog rada je prikaz modela za predviđanje otvaranja stečajnog postupka razvijenih u specifičnim tržišnim uslovima koji vladaju u Republici Srbiji i poređenje njihove preciznosti predviđanja sa, u praksi najčešće korišćenim, Altmanovim Z-score modelom. Mnogi autori iz ove oblasti su razvili modele, ali najčešće u uslovima razvijenih tržišta i privrednog rasta. $U$ radu smo prikazali tri modela koji koriste standardne i određene specifične finansijske pokazatelje, a u cilju predviđanja otvaranja stečajnog postupka u tržištima u razvoju sa karakteristikama recesije. S tim ciljem, na inicijalnom uzorku (130 privrednih društava) smo upotrebili sledeće statističke metode i metode mašinskog učenja: metod logističke regresije, metod stabala odlučivanja i metod veštačkih neuralnih mreža. Na test uzorku (102 privredna društva) smo uporedili preciznost predviđanja novoformiranih modela sa preciznošću predviđanja Altmanovih Z-score modela. Rezultati pokazuju da od pomenuta 3 modela, na nezavisnom test uzorku,jedino model neuralnih mreža pokazuje bolje rezultate u poređenju sa Altmanovim Z-score modelima.

Ključne reči: Tržišta u razvoju, Altmanov Z-score, modeli predviđanja stečaja, finansijski pokazatelji, metoda veštačkih neuralnih mreža.

\section{Introduction}

Having in mind that almost 700.000 corporate bankruptcies have occurred in European Union member states between 2008-2011 and the fact that financial crises are more and more frequent with far-reaching and profound effects, the importance of business default prediction becomes evermore important (Mizdrakovic, 2012). Lenders and investors have to be more rigorous in their analysis and prediction of their client's solvency. Although this analysis in modern surroundings involves different information and factors, including non-financial and qualitative ones, traditional analysis of financial reports via financial indicators remains one of the most used elements. The selection of relevant financial indicators has typically been accomplished through the implementation of statistical methods. It is to be anticipated that within the analysis of financial reports in difficult market conditions, certain variables lose their explanatory power, hence we might assume that their places have been taken by some other, maybe more relevant indicators. Furthermore, it would be useful, as well as interesting, to determine a model which could be applied in financially distressed economies. As a typical representative for the development of this model, we will use the economy of the Republic of Serbia. Negative effects of the world economic crisis have started to emerge in this country in 2009, 2010 and 2011, when a large number of companies ceased their operations (Stanisic, Radojevic, 
Mizdrakovic \& Stanic, 2012). Therefore, we do consider that analysis of financial reports must be conducted within these reporting periods for the establishment of a suitable model. The main aim of this research is to accordingly form a model which could assess the probability of corporate bankruptcy in the Republic of Serbia two years before it actually happens, with an acceptable confidence level. To do so, we will calculate over 30 financial indicators based on the financial reports of 232 selected entities and use logistic regression, decision trees and artificial neural networks to construct appropriate models. The paper will be structured in the following manner: first, we will present some of the most important research results within the area of bankruptcy prediction; after that, we will present the manner of selection for the companies comprising the research sample, and finally we will present the model which was obtained with the implementation of the statistical methods on the training sample. Finally, we will present the research results in terms of comparisons of the defined models with Altman's models.

\section{Literature Review}

The most well-known studies from this area were reported by Altman within his papers in 1968 and 2002. It is interesting that the results of both studies show that the reliability of company bankruptcy prediction reaches its maximum up to two years prior to bankruptcy being declared and reliability drastically drops after that period (Altman, 2002). Therefore, we will present research results up to two years prior to bankruptcy filing, although it is generally considered that financial indicators may present a certain level of reliability in bankruptcy prediction even up to five years ahead of time (Mizdrakovic, 2012).

The first of the mentioned studies was published within the period 1946-1965 (Altman, 1968), significantly after the Great Depression and the cancellation of fair values for controversial methods of property value assessment. The research carried out by Beaver and colleagues (2005) may seem also interesting - the same relates to the impact of the Financial Accounting Standards Board (FASB) and standards taken by this organization which are mostly oriented towards an increase in the use of the fair value method. The authors have concluded that a drop in reliability of financial indicators in predicting insolvency proceedings is the consequence of the improvement in quality in market-based indicators (Beaver et al., 2005). Regarding the methodology, authors like Campbell et al and Bharath and Shumway (2008) used reduced form models of bankruptcy prediction and hybrid models using characteristics of both structural and reduced form models. 
A second study carried out by Altman covered the period from 1977 to 1999. It was mentioned in this paper that the highest number of insolvency proceedings in that period was from 2001 and 2002 (Altman, 2002), when c. 30.000 proceedings were filed; however, during 2010 and 2011, this number doubled. The formula for calculating the probability of insolvency proceeding establishment in emerging markets has been modified in the mentioned study and we will use it in this research as a base for comparison with the defined model. However, many authors have discussed and referred to macroeconomic conditions and even to legal systems which might have significant roles in bankruptcy prediction (Boritz et al., 2007). It would be therefore interesting to determine if these factors affect the accuracy of the mentioned methods in predicting insolvency even in the Republic of Serbia.

\section{Research Methodology}

\subsection{Sample Selection}

We will use two samples in this research: the first will be used to define the model for bankruptcy prediction, and the second to test its reliability and compare results with Altman's models. Financial reports of two groups of completely different companies have been used for the establishment of the mentioned models. The first group comprises of 65 entities with insolvency proceedings filed in 2011, while the other group contains the same number of sound companies, so that we could compare their financial positions through certain indicators presented within financial reports (Mizdrakovic, 2012). The selection of bankrupted companies has been carried out in line with the availability of financial reports, while the sound companies have been selected randomly (by computer). All entities belong to big or medium size classification groups, which provides a matching in order to identify appropriate control firms, as has been done in similar studies (Shumway, 2001). The training sample accordingly consists of financial reports of 130 companies in total and a test sample consists of 102 completely different companies. Data from financial reports have been taken from a government body responsible for the registration and tracking of company business activates in the Republic of Serbia. The selected companies come from various sectors, as listed in table 1, and their average assets value amounts to c. US\$7 million. We used data from financial reports from 2009 and 2010, which presented the period of two years prior to bankruptcy being declared, to assess the reliability of bankruptcy prediction. Companies with incomplete reports, or those that have no reports at all for both mentioned years were excluded from the sample. Companies in the Republic of Serbia are not obliged to submit financial reports on a quarterly basis which would be of 
Stanišić N. et al.: Corporate Bankruptcy Prediction in the Republic of Serbia

significance in the establishment of a more precise model, but they have to submit financial statements for a one-year period.

Table 1. Entities included in training and test sample split according to their core business

\begin{tabular}{|c|c|c|c|c|c|}
\hline \multirow[b]{2}{*}{ Core business } & \multicolumn{2}{|c|}{ Training sample } & \multicolumn{2}{|c|}{ Test sample } & \multirow[b]{2}{*}{ Total } \\
\hline & $\begin{array}{l}\text { No. of } \\
\text { bankrupted } \\
\text { companies }\end{array}$ & $\begin{array}{c}\text { No. of } \\
\text { sound } \\
\text { companies }\end{array}$ & $\begin{array}{c}\text { No. of } \\
\text { bankrupted } \\
\text { companies }\end{array}$ & $\begin{array}{c}\text { No. of } \\
\text { sound } \\
\text { companies }\end{array}$ & \\
\hline $\begin{array}{l}\text { Agriculture, forestry and } \\
\text { fishery }\end{array}$ & 6 & 4 & 1 & 9 & 20 \\
\hline Mining industry & 1 & 1 & 0 & 0 & 2 \\
\hline Processing industry & 31 & 16 & 20 & 16 & 83 \\
\hline $\begin{array}{l}\text { Electricity, gas, steam } \\
\text { and air-conditioning } \\
\text { supplying }\end{array}$ & 0 & 1 & 0 & 0 & 1 \\
\hline $\begin{array}{l}\text { Water supplying and } \\
\text { waste water } \\
\text { management }\end{array}$ & 1 & 3 & 0 & 1 & 5 \\
\hline Civil engineering & 11 & 7 & 11 & 5 & 34 \\
\hline $\begin{array}{l}\text { Wholesale and retail- } \\
\text { sale }\end{array}$ & 8 & 21 & 14 & 16 & 59 \\
\hline $\begin{array}{l}\text { Transportation network } \\
\text { and warehousing }\end{array}$ & 2 & 6 & 0 & 0 & 8 \\
\hline $\begin{array}{l}\text { Accommodation and } \\
\text { catering services }\end{array}$ & 0 & 2 & 1 & 2 & 5 \\
\hline $\begin{array}{l}\text { Information and } \\
\text { communication } \\
\text { technologies }\end{array}$ & 3 & 2 & 1 & 0 & 6 \\
\hline $\begin{array}{l}\text { Financial and insurance } \\
\text { activities }\end{array}$ & 1 & 0 & 1 & 0 & 2 \\
\hline Real estate industry & 1 & 0 & 1 & 0 & 2 \\
\hline $\begin{array}{l}\text { Professional, scientific, } \\
\text { innovation and technical } \\
\text { activities }\end{array}$ & 0 & 1 & 0 & 2 & 3 \\
\hline $\begin{array}{l}\text { Art, entertainment and } \\
\text { recreation industry }\end{array}$ & 0 & 1 & 0 & 0 & 1 \\
\hline $\begin{array}{l}\text { Administrative and } \\
\text { supporting activities }\end{array}$ & 0 & 0 & 1 & 0 & 1 \\
\hline Total & 65 & 65 & 51 & 51 & 232 \\
\hline
\end{tabular}

Source: (Mizdrakovic, 2012)

In order to avoid overfitting, a hold-out sample has been established. We formed it in order to test the defined model and make comparisons with 
Altman's formula presents financial reports of 51 companies with insolvency proceedings being established in the period between January to July 2012. A total number of 732 companies filed for bankruptcy in that period, out of which the majority represent small legal entities and entrepreneurs who were not obliged to submit financial reports. The same number of sound companies has been selected randomly (by computer). Dates of insolvency proceeding establishment, as well as availability of financial reports, have been checked for each individual company. It is important to determine the exact time of bankruptcy filing, as well as the timing of availability of financial reports to the public. Namely, there is a possibility that insolvency proceeding is established after a certain fiscal year date, but prior to submission of financial reports by the company, which could have an impact on the process of bankruptcy prediction (Ohlson, 1980).

We do consider it important to draw attention to certain specificities related to running businesses in the Republic of Serbia. Namely, companies have been obliged to publicly disclose financial reports only from 2005; hence the habit of a realistic illustration of financial positions was established within regular businesses only recently. Furthermore, the procedure of privatization of companies which were owned by the state or were public has been carried out in the Republic of Serbia, but not to its full extent since it is not finished yet. There is a realistic danger that during this procedure for certain companies, some artificial conditions have been created for insolvency proceeding establishment due to particular reasons, although these companies could have continued with their regular business activities and vice versa. Moreover, it seems that the use of creative accounting has been established in financial reporting in the Republic of Serbia as a consequence of many years of keeping financial reports as business "secrets" of companies, as well as due to, it seems, less rigorous internal and external auditing. Previous statements can impact research results, having in mind that companies included in both samples were randomly selected (by computer) and not selected by subjective assessment.

\subsection{Methodology}

Following previous studies and on the basis of financial ratios obtained from financial reports we will classify sound companies within one group marked as 0 , while bankrupted companies will be classified within the group marked as 1. After that, we will compare a realistic situation in accordance to official data with research results and we will determine the preciseness of prediction on the basis of information from financial reports (Mizdrakovic, 2012). The procedure of company classification could be done with the application of various statistical and machine learning techniques. 
A method that is commonly used insimilar studies is logistic regression analysis. This method predicts unknown values based on known values of one or more variables - in our case, financial ratios. It actually estimates a relationship between a set of variables (financial ratios) that describes one company and the probability of its default. However, in the last 10 years artificial intelligence methods are often used, of which artificial neural networks (ANN) are considered to be one of the most precise. The results of the research conducted by Ngyen show that these models, which are used in this study as well, are good at predicting corporate failure and probabilistic neural network model outperforms others due to high accuracy levels using both one and two year data before failure (Nguyen, 2005). Actually, ANN methods are expected to produce higher classification accuracy rates than logistic regression methods, because the primary purpose of ANNs is to provide satisfactory results in prediction tests, rather than parameter estimation or hypotheses testing (Youn and Gu, 2010).

Several authors have used neural networks to successfully predict financial phenomena, such as stock market trends, corporate bankruptcy, gold prices and foreign exchange prices (Sen et al., 2004). The main advantage of the logistic regression method over ANN is the understanding of the contribution of every variable in bankruptcy prediction. This method indicates which financial indicators have more significance in bankruptcy prediction, as opposed to ANN where the procedure of determination of bankruptcy occurrence probability and classification of companies as sound or bankrupted is less prominent. Therefore, this research will apply both methods. We will use a multi-layer perceptron network with one hidden layer and hyperbolic tangent activation function. We used the Batch Backpropagation Algorithmand the scaled conjugate gradient method for training a network. One step without a decrease in error (minimum relative change in error 0.0001) is used as a stopping rule.

Besides the stated methods in research regarding bankruptcy prediction, a method based on probability called a decision tree, is also used. The decision tree method encompasses a number of specific algorithms which includes Classification and Regression Trees, Chi-squared Automatic Interaction Detection, C4.5, C5.0 and integration of C4.5 with genetic programming (Lee, 2006). As it has been shown by Lee (2006), the decision tree model yields the best classification accuracy though the approximate decision rules inferred are less intuitive and humanly understandable. In similar research, with a larger sample, accuracies between $86 \%$ and $99 \%$ were obtained, using this model for bankruptcy prediction (Santos, Cortez, Pereira, \& Quintela, 2006).

In table 2 all the indicators used in the sample of company bankruptcy prediction have been presented. The majority of them are well-known financial indicators which have been used within the analysis of financial reports for a 
long time, hence we will neither explain these additionally, nor the manner of indicator calculation. The exception may be adjusted net gain, adjusted indicator ROE and adjusted gain rate which have all the items regarding extraordinary gains and losses excluded.

Table 2. Overview of independent variables used in research

\begin{tabular}{|c|c|c|c|}
\hline \multirow{9}{*}{$\begin{array}{c}\text { Key } \\
\text { Statistics }\end{array}$} & Revenue & \multirow{18}{*}{ Miscellaneous } & Normalized net income \\
\hline & EBITDA & & Normalized ROE \\
\hline & EBIT & & Normalized net margin \\
\hline & Net income & & $\begin{array}{l}\text { Average net salary per } \\
\text { month }\end{array}$ \\
\hline & Total assets & & Interest expense \\
\hline & Total equity & & Interest rate \\
\hline & Invested capital & & Payout ratio \\
\hline & Cash \% & & Implied growth rate \\
\hline & Number of employees & & Sustainable growth rate \\
\hline \multirow{6}{*}{ Profitability } & ROE & & Net income volatility \\
\hline & ROA & & Net working capital \\
\hline & $\begin{array}{l}\text { Return on invested } \\
\text { capital }\end{array}$ & & Net change in debt \\
\hline & Net margin & & Net capital expenditure \\
\hline & Operating margin & & Free cash flow to equity \\
\hline & Free cash flow margin & & Free cash flow to firm \\
\hline \multirow{3}{*}{$\begin{array}{l}\text { Financial } \\
\text { leverage }\end{array}$} & Debt ratio & & Foreign ownership \% \\
\hline & $\begin{array}{l}\text { Interest bearing debt to } \\
\text { assets }\end{array}$ & & Revenue growth rate \\
\hline & Interest coverage ratio & & Days sales outstanding \\
\hline \multirow{3}{*}{ Liquidity } & Current ratio & \multirow{3}{*}{ Cash cycle } & $\begin{array}{l}\text { Days } \\
\text { outstanding }\end{array}$ \\
\hline & Quick ratio & & $\begin{array}{l}\text { Inventory conversion } \\
\text { period }\end{array}$ \\
\hline & $\begin{array}{l}\text { Net working capital to } \\
\text { revenue }\end{array}$ & & Cash conversion period \\
\hline
\end{tabular}

Source: (Mizdrakovic, 2012)

We will verify the precision of the defined models on the aforementioned holdout sample and we will compare them with Altman's models. The original formula of Altman's Z-score will not be applied in this paper due to the unavailability of data on market value of the sampled companies; however, we will apply a model for private companies. Besides this model, we will also apply a model constructed later in the work dating from 2002, dedicated to bankruptcy prediction in difficult market conditions and emerging markets. As market conditions in Serbia fall under this category, we consider that the implementation of this formula is justified, since it could deliver more precise results in comparison to the original formula. 
$Z^{\prime}=.717 X_{1}+.847 X_{2}+3.107 X_{3}+.420 X_{4}+.998 X_{5}$

$Z^{\prime \prime}=6.56 X_{1}+3.26 X_{2}+6.72 X_{3}+1.05 X_{4}$

Where $X n$ represents the following:

$X_{1}$ - working capital/total assets,

$X_{2}$ - retained earnings/total assets,

$X_{3}$ - earnings before interest and taxes/total assets,

$X_{4}$ - book value of equity/total liabilities and

$X_{5}$ - sales/total assets

\section{Results}

We will first present the research results, as well as the methods applied. We will then present the research results on the hold-out sample. Data on which we applied the methods has been collected from the financial reports which are compiled two years prior to insolvency. Bankruptcy prediction is certainly much more precise within a year prior to insolvency, but it is also less useful and therefore those results will not be presented in this paper. Table 3 shows the results of bankruptcy prediction using all three methods - logistic regression, neural networks (multilayer perceptron) and decision trees - on the sample which formed the basis for our model.

Table 3. Precision of the modelswhen applied to the training sample

\begin{tabular}{|c|c|c|c|c|c|c|}
\hline Methods & \multicolumn{2}{|c|}{ Logistic regression } & \multicolumn{2}{|c|}{ Multilayer perceptron } & \multicolumn{2}{c|}{ Decision trees } \\
\hline Overall & - & $75.4 \%$ & - & $79.2 \%$ & - & $75.4 \%$ \\
\hline 0 & $45 / 65$ & $69.2 \%$ & $42 / 65$ & $64.6 \%$ & $49 / 65$ & $75.4 \%$ \\
\hline 1 & $53 / 65$ & $81.5 \%$ & $61 / 65$ & $93.8 \%$ & $49 / 65$ & $75.4 \%$ \\
\hline
\end{tabular}

Source: (Mizdrakovic, 2012)

The percentages presented in table 3 show how reliable the sorting of entities to sound ones and those in bankruptcy is. As an example, logistic regression shows that, based on the financial indicators, 45 sound companies have been properly classified as such, out of 65 , which means that preciseness is close to $70 \%$. On the other hand, the model is much more precise in sorting the bankrupt companies, since it sorted 53 as bankrupt companies out of 65 . The reason for this difference may be the quality of financial reporting in the Republic of Serbia. There are many more reasons to use forbidden tools of creative accounting to present the financial health of a company as sound rather than the opposite, which means that the presented model may have 
recognized a sound entity as one that has endangered financial health with a reason.

In table 3 you may also note that the utmost preciseness in terms of classification of entities into sound and bankrupted ones has been achieved with the application of the multilayer perceptron method, which matches most of the results carried out in similar studies. However, the advantage which logistic regression possesses is the insight into importance of certain variables in bankruptcy prediction. As a result, the formula which might be used in future studies or prediction of insolvency could be determined. The following formula was created as a result of the appliance of the logistic regression method:

$M=-.00039 X_{1}+.003786 X_{2}+.997167 X_{3}-1.900213 X_{4}$

Where $X n$ represents the following:

$X_{1}-$ EBITDA

$X_{2}-$ Number of employees

$X_{3}-$ Debt ratio

$X_{4}-$ Sales to total assets.

It is interesting that one of the indicators which has a considerable significance in bankruptcy prediction is not in form of ratio, but rather an absolute variable; that is, the number of employees. According to the formula, the larger the number of employees, the higher the probability of insolvency. The number of employees may be a good indicator for market conditions, such as those in the Republic of Serbia, and there are two explanations for this. State owned companies have been artificially kept alive which was in accordance with the social policy of not making employees redundant, which was considered as apolitically unpopular act. Also, the negative impact of the world economic crisis was mostly sensed in 2010 and 2011, hence entities have not had enough time to align their number of employees to current market conditions by a suitable workforce policy. An inefficient number of employees brought a consequence of high costs for companies in terms of contributions and payroll taxes. Financial results from these two years are comprised within this research sample. Abnormal reductions in the number of employees have also been perceived as a useful tool for detecting misstatements. Authors noticed that cutting employees directly improves short run earnings performance by lowering wage expenses and that physical assets and labor should be substitutes meaning that decrease in employees relative to total assets could signal overstated asset balances (Dechow et al, 2011).

It is also important to emphasize that every model might be wrong in bankruptcy prediction in two ways, and although the significance of the 
mistake is the same with both mistake types, most of the authors agrees that type I mistakes are much more "expensive" and important; that is, can inflict much more damage than type II mistakes. Type I mistakes could inflict damage to a financial institution which could approve loans to an insolvent entity; it could also inflict damage to an auditor who would form misleading opinions on the basis of the applied model (Nanda and Pendharkar, 2001). With type II mistakes, potential losses could be created if shares of a company predicted to go into bankruptcy are sold prior to the original plan for share selling. Out of the previously presented table we may see that the defined model in this paper creates much more mistakes in classifying sound companies as being such; that is, mistake type I occurs more frequently in comparison to mistake type II.

Figure 1. Precision of the applied models on the hold-out sample

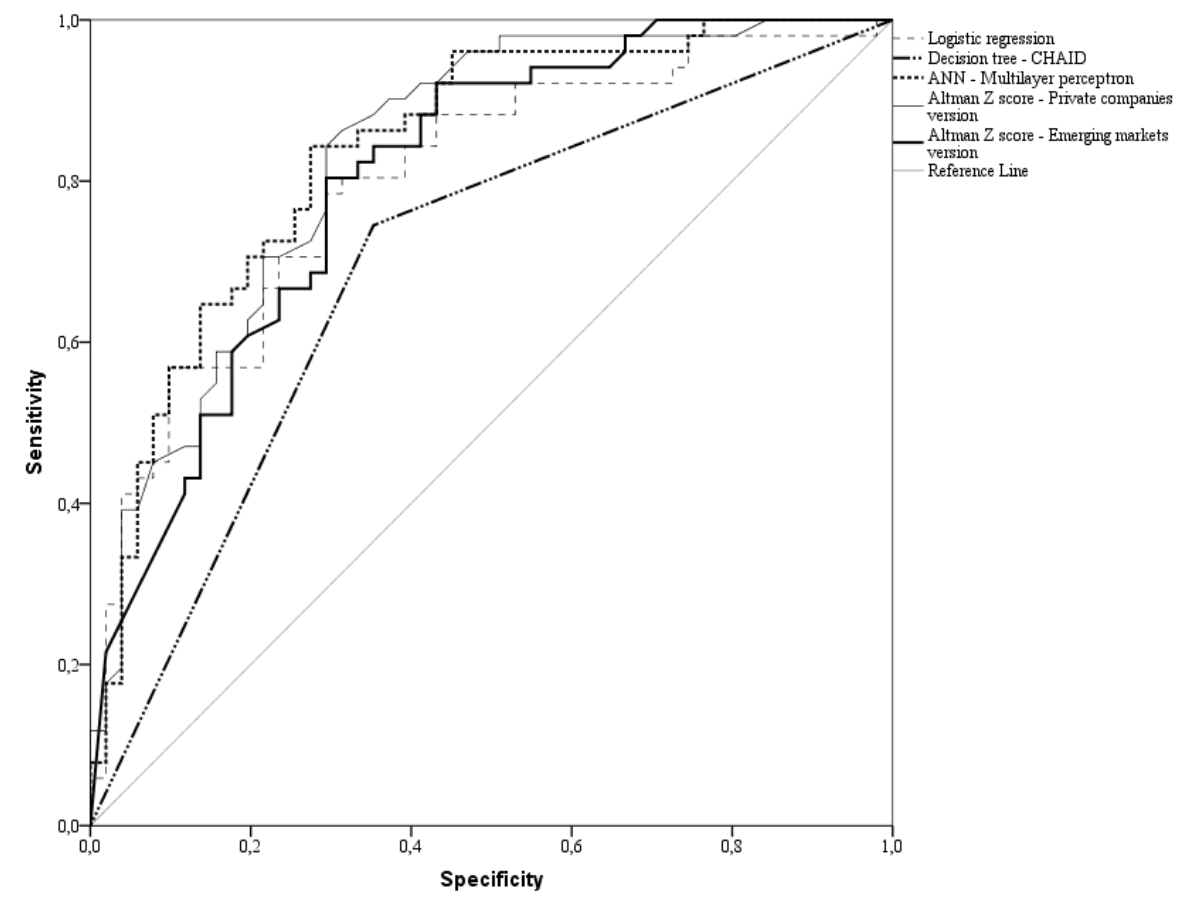

Source: (Mizdrakovic, 2012)

In order for the defined model to be considered relevant, its reliability has to be tested on the hold-out sample and compared with the two previously mentioned models constructed by Edward Altman. Therefore, we have 
applied the logistic regression, multilayer perceptron and decision tree methods on a hold-out sample. In fig. 1, with use of the recovery operating characteristic (ROC) curve, we have compared results of the application of the research models.

For a comparison of the precision of the applied models we will use the area under the ROC curve or so-called AUC. As a rule, all the curves above the reference line, which has been set under the angle of 45 degrees, are much more precise in predicting insolvency proceeding establishment than the model of random selection (Dakovic et al., 2010). In general, the steeper and closer the curve is to the $\mathrm{Y}$ axis, the model is more precise in insolvency prediction versus the other models (Deventer and Imai, 2003). Furthermore, a suitable ratio for comparison of preciseness of the considered models could be calculated on the basis of this curve. Generally speaking, the ROC curve provides betters results if the entities are split into several categories instead of just two categories - sound ones and those which went into bankruptcy (Jayadev, 2006). We could have used credit ratings of the entities for mentioned classification; however, since they are still not being used in the economy of the Republic of Serbia, we leave that consideration for future work.

Table 4. Area under ROC curve for the applied models

\begin{tabular}{|c|c|c|c|c|c|}
\hline \multirow{2}{*}{$\begin{array}{l}\text { Test Result } \\
\text { Variable(s) }\end{array}$} & \multirow[t]{2}{*}{ Area } & \multirow{2}{*}{$\begin{array}{l}\text { Std. } \\
\text { Error }\end{array}$} & \multirow{2}{*}{$\begin{array}{l}\text { Asymptotic } \\
\text { Significance }\end{array}$} & \multicolumn{2}{|c|}{$\begin{array}{c}\text { Asymptotic } 95 \% \\
\text { Confidence } \\
\text { Interval }\end{array}$} \\
\hline & & & & $\begin{array}{l}\text { Lower } \\
\text { Bound }\end{array}$ & $\begin{array}{l}\text { Upper } \\
\text { Bound }\end{array}$ \\
\hline $\begin{array}{l}\text { Multilayer } \\
\text { perceptron } \\
\text { (Neural } \\
\text { Networks) }\end{array}$ & .839 & .039 & .000 & .761 & .916 \\
\hline $\begin{array}{c}\text { Altman - private } \\
\text { companies }\end{array}$ & .833 & .040 & .000 & .755 & .911 \\
\hline $\begin{array}{c}\text { Altman - } \\
\text { emerging } \\
\text { markets }\end{array}$ & .804 & .043 & .000 & .719 & .888 \\
\hline $\begin{array}{c}\text { Logistic } \\
\text { regression }\end{array}$ & .801 & .044 & .000 & .715 & .887 \\
\hline Decision trees & .696 & .053 & .001 & .593 & .800 \\
\hline
\end{tabular}

Source: (Mizdrakovic, 2012) 
Table 4 shows the results of the model comparison where, as well as on the previously presented figure 1 with the ROC curve, it can be seen that the best results were achieved with the multilayer perceptron. Altman's formula for private companies follows closely and one might say that it is exceptionally precise as well, although not constructed in the conditions similar to those in the Republic of Serbia. Altman's formula for emerging economies and challenging economic conditions is significantly weaker in comparison to the other two and it is close to logistic regression constructed in this research in terms of preciseness. The weakest prediction results are achieved by the decision tree method, which could have been expected based on outputs of similar studies.

\section{Conclusions}

Having in mind that the number of bankrupted companies in the Republic of Serbia has increased significantly and that general solvency has been in a steady decline in the last couple of years, as well as the specificities related to the economy of the Republic of Serbia, we found it necessary to construct models which would be suitable for other emerging economies as well. In addition, we defined a logistic regression model which could assist banks and other financial institutions in quite a reliable assessment of companies which could go into bankruptcy within a two year period. Depending on the selected method, models defined in this paper provide similar results in comparison to the frequently used Altman models in insolvency prediction. As it was noticed in this paper's research, multilayer perceptron (Neural Network) method provides better results in bankruptcy prediction in comparison to the other methods. In similar research conducted in the United Kingdom, the Neural Network model achieved the highest overall classification rates, as well, with an average classification rate of $78 \%$ (Charitou, Neophytou, \& Charalambous, 2004). On the basis of the obtained results, we consider that the implementation of Altman's model is acceptable in bankruptcy prediction in the Republic of Serbia. It would be interesting to apply defined models to data from financial reports of companies from emerging markets in the same region. In our future work, we will examine the consistency of the defined model on new samples and try to develop it into a useful asset in bankruptcy prediction in the Republic of Serbia.

\section{References}

Altman , E. (1968). Financial Ratios, Discriminant Analysis and Prediction of Corporate Bankruptcy. Journal of Finance, 23 (4), pp. 589-609. 
Altman, E. (2002). Corporate Distress Prediction Models in a Turbulent Economic and Basel II Environment. Accessed on January 13, 2013, at NYU Stern School of Business: http://pages.stern.nyu.edu/ ealtman/Corp-Distress.pdf

Beaver, W., et al. (2005). Have Financial Statements Become Less Informative? Evidence From the Ability of Financial Ratios to Predict Bankruptcy. Review of Accounting Studies, 10 (1), pp. 93-122.

Bharath, S., \& Shumway, T. (2008). Forecasting Default with the Merton Distance to Default Model. Review of Financial Studies, 21 (1), pp. 1339-69.

Boritz, E., et al. (2007). Predicting Business Failures in Canada. Accounting Perspectives, 6 (2), pp. 141-165.

Campbell, J., Hilscher, J., \& Szilagyi, J. (2008). In Search of Distress Risk. The Journal of Finance, 63 (1), pp. 2899-939.

Charitou, A., Neophytou, E., \& Charalambous, C. (2004). Predicting Corporate Failure: Empirical Evidence for the UK. European Accounting Review, 13 (3), pp. 465 497.

Dakovic, R., et al. (2010). Bankruptcy Prediction in Norway: A Comparison Study. Applied Economics Letters, 17 (17), pp. 1739-46.

Dechow, P., et al. (2011). Predicting Material Accounting Misstatements. Contemporary Accounting Research, pp. 17-82.

Deventer, D., \& Imai, K. (2003). Credit Risk Models and the Basel Accords. Singapore: John Wiley and Sons.

Jayadev, M. (2006). Predictive Power of Financial Risk Factors: An Empirical Analysis of Default Companies. Vikalpa, 31 (3), pp. 45-56.

Lee, W. (2006). Genetic Programming Decision Tree for Bankruptcy. Proceedings of the 2006 Joint Conference on Information Sciences (pg. 2568-2583). Kaohsiung: JCIS.

Mizdrakovic, V. (2012). Komparativna analiza ekonomskih aspekata stečaja (Comparative analysis of the economic aspects of bankruptcy). Accessed on December 28, 2012, at Singipedia - Singidunum University: http://www.singipedia.com/content/3276-Komparativna-analiza-ekonomskihaspekata-ste\%C4\%8Daja

Nanda, S., \& Pendharkar, P. (2001). Linear Models for Minimizing Misclassification Costs in Bankruptcy Prediction. International Journal of Intelligent Systems in Accounting, Finance and Management, 10 (3), pp. 155-168.

Nguyen, H. G. (2005). Using Neutral Network in Predicting Corporate Failure. Journal of Social Sciences 1 (4), pp. 199-202.

Ohlson, J. (1980). Financial Ratios and the Probabilistic Prediction of Bankruptcy. Journal of Accounting Research, 18 (1), pp. 109-131.

Santos, M., Cortez, P., Pereira, J., \& Quintela, H. (2006). Corporate Bankruptcy Prediction Using Data Mining Techniques. WIT Transactions on Information and Communication Technologies, 37 (1), pp. 349-357.

Sen, T., et al. (2004). Improving Prediction of Neural Networks: A Study of Two Financial Prediction Tasks. Journal of Applied Mathematics and Decision Sciences, 8 (4), pp. 219-233.

Shumway. T. (2001). Forecasting Bankruptcy More Accurately: A Simple Hazard Model. Journal of Business, 74 (1), pp. 103-224.

Stanisic, N., Radojevic, T., Mizdrakovic, V., \& Stanic, N. (2012). Capital Efficiency Analysis of Serbian Companies. Singidunum Journal of Applied Sciences, 9 (2), pp. 41-49. 
Stanišić N. et al.: Corporate Bankruptcy Prediction in the Republic of Serbia

Youn, H., \& Gu, Z. (2010). Predict US Restaurant Firm Failures: The Artificial Neural Network Model Versus Logistic Regression Model. Tourism and Hospitality Research, 10 (3), pp. 171-187. 